\title{
Régi és új orális antikoagulánsok hazai alkalmazása pitvarfibrillációban
}

\author{
Tomcsányi János dr. ${ }^{1}$ - Salfer Balázs ${ }^{2}$ - Nagy Bence dr. ${ }^{2}$ \\ ${ }^{1}$ Betegápoló Irgalmasrend Budai Irgalmasrendi Kórház, Kardiológia, Budapest \\ ${ }^{2}$ Healthware Tanácsadó Kft., Budapest
}

Bevezetés: A pitvarfibrilláció kezelésében a régi és az új antikoagulánsok jelentősen csökkentik a stroke és mortalitás előfordulását.

Célkitüzés: Annak felderítése, hogy az elmúlt időben a pitvarfibrillációt elszenvedő betegek milyen arányban kaptak hatásos stroke-profilaxist, és milyen volt ezeknek a betegeknek a gyógyszer-adherenciája.

Módszer: Az OEP/NEAK adatbázisában szereplő, pitvarfibrillációt elszenvedő betegekre vonatkozó adatgyüjtés. A vizsgált időszak: 2010-2015. Azok a betegek kerültek beválogatásra, akiknek ez idő alatt legalább egyszer szerepelt az I48 BNO-kód a nyilvántartásában. Adherensnek tekintettük azokat a betegeket, akik legalább 80\%-ban kiváltották a receptjeiket.

Eredmények: Magyarországon 3\% a pitvarfibrilláció prevalenciája. Az adott évben egészségügyi ellátásra kerülő, pitvarfibrilláló betegek mortalitása 7-10\% közötti. A betegek egyharmada nem kap effektív stroke-profilaxis kezelést. A legutolsó, 2015. évet figyelembe véve az adherencia 55\% volt a K-vitamin-antagonistát szedóknél, míg 69,7\% a direkt antikoagulánst szedőknél.

Következtetések: Az új orális antikoagulánsok bevezetésével javítható volt a betegek adherenciája, de még mindig magas az effektív stroke-profilaxisban nem részesülők aránya.

Orv Hetil. 2017; 158(39): 1545-1549.

Kulcsszavak: pitvarfibrilláció, antikoaguláció, K-vitamin-antagonista, új orális nem K-vitamin-antagonista, adherencia

\section{Old and new oral anticoagulants in the management of atrial fibrillation. Hungarian data}

Introduction: Despite a progress in the management of patients with atrial fibrillation this arrhythmia is one of the major causes of stroke, heart failure, sudden death and cardiovascular morbidity. Oral anticoagulation with vitamin $\mathrm{K}$ antagonist or non-vitamin $\mathrm{K}$ antagonist markedly reduces stroke and mortality in atrial fibrillation patients.

Aim: To estimate the real-life vitamin $\mathrm{K}$ antagonist and non-vitamin $\mathrm{K}$ antagonist oral anticoagulant treatment in past years in Hungary.

Method: Analysis of the National Health Insurance Administation database for atrial fibrillation (BNO: I48) between 2010-2015. We assumed that AF patient would turn to health care provides at least once either as inpatients or outpatients in a 5 -year period. The patient was accepted as adherent after 6 months therapy and at least $80 \%$ oral anticoagulant prescription.

Results: The prevalence of AF in Hungary is 3\%. The mortality rate of AF 7\%-10\% per year. The adherence of the old oral anticoagulant treatment was $55 \%$, but it was $69 \%$ among patient treated by "new" oral anticoagulant treatment. However, one third of the patients are not treated by effective old or new oral anticoagulant treatment.

Conclusions: We need more effort to improve the effective and high adherence oral anticoagulant therapy in our country.

Keywords: atrial fibrillation, anticoagulation, vitamin $\mathrm{K}$ antagonists, non-vitamin $\mathrm{K}$ antagonist, prevalence, adherence

Tomcsányi J, Salfer B, Nagy B. [Old and new oral anticoagulants in the management of atrial fibrillation. Hungarian data]. Orv Hetil. 2017; 158(39): 1545-1549. 


\section{Rövidítések}

$\mathrm{AF}=$ pitvarfibrilláció; $\mathrm{BNO}=$ Betegségek Nemzetközi Osztályozása; $\mathrm{CHA}_{2} \mathrm{DS}_{2}$-VASc score = a stroke rizikójának meghatározására használt mozaikszó; DOAC $=$ direkt orális antikoaguláns; INR $=$ (International Normalized Ratio) nemzetközi normalizált ráta (a véralvadásgátló hatásosságának kifejezése); KVA = K-vitamin-antagonista; NEAK = Nemzeti Egészségbiztosítási Alapkezelő; NOAC = új orális antikoaguláns (új típusú véralvadásgátló); $\mathrm{OEP}=$ Országos Egészségbiztosítási Pénztár; REPOSI = REgistro POliterapie Società Italiana

A pitvarfibrilláció a leggyakoribb ritmuszavar, aminek súlyos cardiovascularis következményei vannak, illetve lehetnek. Hazai viszonylatban a prevalenciája $3 \%$ körül van [1]. A pitvarfibrilláció kezelésének legfontosabb eleme a stroke-profilaxis, aminek kezelése az utóbbi évtizedben lényeges változásokon ment keresztül [2].

E változások két legfontosabb eleme, hogy az aszpirin kikerült a stroke-profilaxis ajánlott gyógyszerei közül, a nem K-vitamin-antagonista orális antikoagulánsok viszont - az elmúlt évek meggyőző vizsgálatai alapján - a stroke-profilaxisnak meghatározó elemei [3-6].

A REPOSI vizsgálatból az derült ki, hogy akik a stroke-profilaxis szempontjából az ajánlásoknak megfelelő kezelésben részesülnek, azoknak mind az összhalálozása, mind a cardiovascularis halálozása szignifikánsan alacsonyabb, mint akik nem az ajánlásoknak megfeleló kezelést kapják [7]. Éppen ezért tanulmányunknak az volt a célja, hogy felderítse, az elmúlt időben a pitvarfibrilláló betegek milyen arányban kaptak hatásos stroke- profilaxist. Ezen belül hogyan változott a K-vitamin-antagonista és nem K-vitamin-antagonista készítmények aránya, és milyen volt a betegek adherenciája ezekhez a készítményekhez.

\section{Betegek és módszer}

Retrospektív adatgyưjtő vizsgálat a NEAK adatbázisában szereplő, pitvarfibrillációban szenvedő betegekre vonatkozóan. A vizsgált időszak a 2010-2015 közötti öt év volt. A prevalencia megállapításához a már korábban is alkalmazott módszert használtuk [1]. Ennek tükrében a 2010-2015 közötti időszakból a 2015. évi adatok tükrözik leginkább a hazai prevalenciát, amikor az adott év mellett az elmúlt négy évben megjelent és életben lévő, de adott évben I48-as BNO-lejelentéssel nem szükségszerúen szereplő betegek is beszámításra kerültek. Így nagy valószínüséggel „minden” pitvarfibrilláló beteg észlelésre kerül, azt feltételezve, hogy ötévente valamikor csak jelentkezett orvosi ellátásra vagy váltott ki gyógyszert. Azok a betegek kerültek beválogatásra, akiknél ez idő alatt legalább egyszer szerepelt az I48-as BNO-kód. Ez szerepelhetett a kórházi/rendelőintézeti ellátás során vagy pedig a kiváltott vényen. Adherensnek a $80 \%$ vagy a feletti gyógyszerkiváltás felelt meg. Sem a K-vitamin-antagonistáknál, sem a nem K-vitamin-antagonistáknál nem lettek a különböző gyógyszerek egymástól elkülönítve. A vizsgálatnak ugyanígy nem volt része a vérhígító gyógyszer alul- vagy felüldozírozásának a vizsgálata.

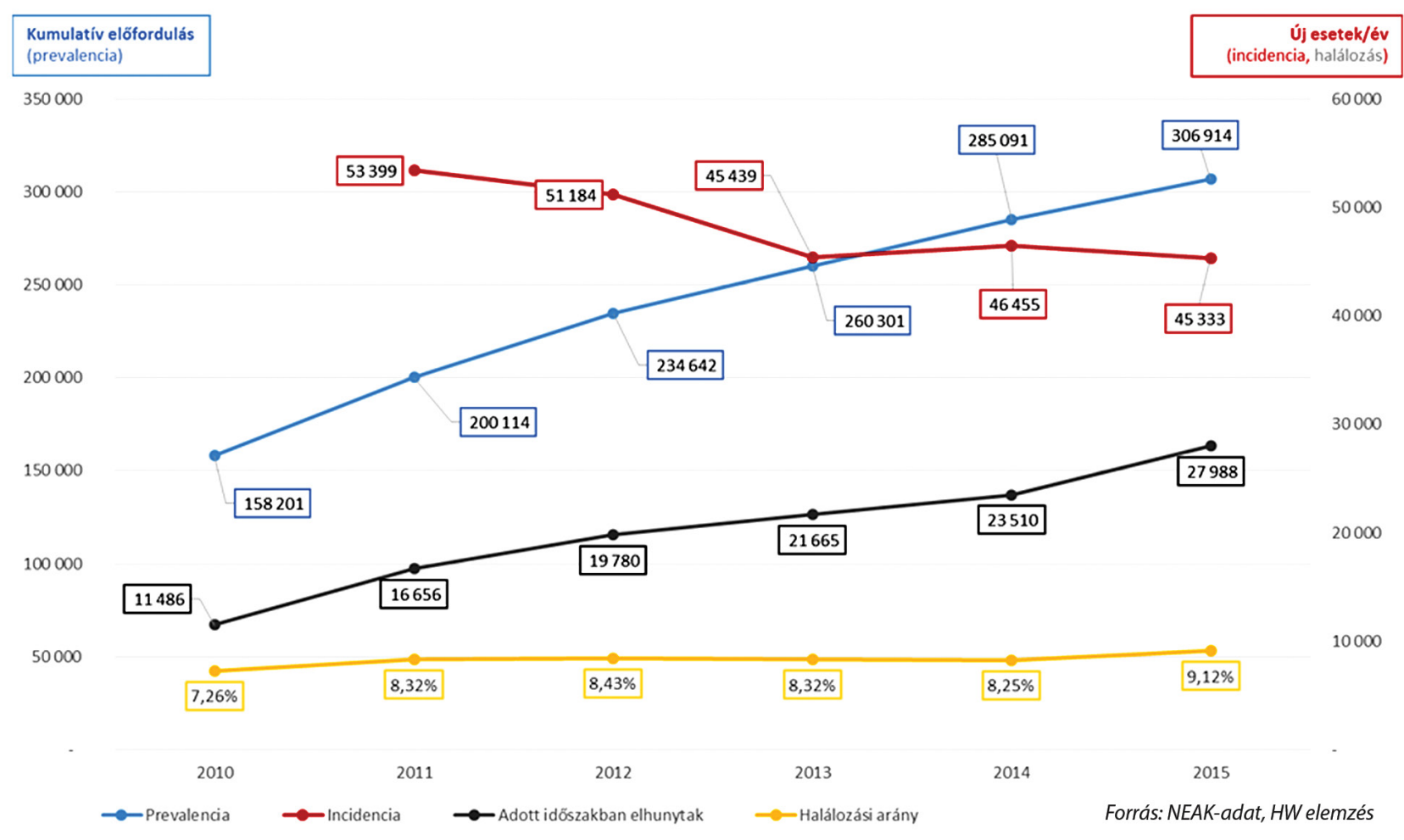

1. ábra | Az I48 BNO-kóddal jelzett legfontosabb populációs adatok 2010-2015 között magyar pitvarfibrilláló betegeknél 


\section{Eredmények}

A pitvarfibrilláció 2010-2015 időszakára vetített prevalenciás és incidenciás adatai mellett a mortalitási adatait is mutatja az 1. ábra. A prevalencia tekintetében a fokozatos növekedést az okozza, hogy 2011-től figyelembe vettük az előző év(ek) betegeit is. Ezek alapján a 2010-es év jelenti azt a betegszámot, ami az adott évben megjelent pitvarfibrilláló egyének számát jelenti, míg a 2015ös év jelenti az adott év és az elmúlt négy évben valamikor is megjelent és 2015-ig életben lévő egyének számát. Ezek alapján prevalenciára a leginkább a 2015-ös adat vehetô, ami azt jelenti, hogy 3\%-os a pitvarfibrilláció ha- zai prevalenciája. Ez körülbelül megegyezik azzal a számmal, amit korábban mértünk a hazai adatokra [1]. Míg a halálozás szempontjából leginkább a 2010-es év a mérvadó, ami azt jelenti, hogy az adott évben egészségügyi ellátásra kerülő pitvarfibrilláló betegek éves mortalitása $7 \%$ felett van. Ami természetesen nem önmagában a ritmuszavarral magyarázható, hanem ebbe belejátszanak a kísérő társbetegségek (infarktus, szívelégtelenség stb.) mortalitásnövelő hatásai is.

A vizsgálatunk következő, legfontosabb kérdése az volt, hogy a betegek milyen arányban részesülnek strokeprofilaxis szempontjából effektívnek mondható K-vitamin-antagonista vagy a direkt antikoaguláns (DOAC)

1. táblázat |Az orális antikoaguláns terápiában részesülők és az effektív stroke-profilaxist nem kapók számának megoszlása az egyes években

\begin{tabular}{|c|c|c|c|c|c|c|c|}
\hline Beteg-alcsoport & 2010 & 2011 & 2012 & 2013 & 2014 & 2015 & $\begin{array}{c}\text { Teljes vizsgálati } \\
\text { időszak }\end{array}$ \\
\hline Nincs terápia & 49953 & 71207 & 88943 & 106101 & 117019 & 126712 & 128545 \\
\hline Releváns terápia & 108248 & 128907 & 145699 & 154200 & 168072 & 180202 & 271466 \\
\hline Összesen & 158201 & 200114 & 234642 & 260301 & 285091 & 306914 & 400011 \\
\hline
\end{tabular}

2. táblázat |A nem effektív kezelést kapók megoszlása az acetilszalicilsavat versus semmit nem szedők között

\begin{tabular}{lcccccccc}
\hline Beteg-alcsoport & 2010 & 2011 & 2012 & 2013 & 2014 & 2015 & Teljes vizsgálati idószak \\
\hline Nem gyógyszeres csoport & 31721 & 46539 & 63893 & 80864 & 89982 & 104566 & 83278 \\
\hline Aspirin & 18232 & 24668 & 25050 & 25237 & 27037 & 22146 & 45267 & \\
\hline
\end{tabular}

3. táblázat |A K-vitamin-antagonista és nem K-vitamin-antagonista új szerek közötti megoszlás az orális antikoaguláns kezelésben részesülőknél

\begin{tabular}{lrrrrrrrr}
\hline Beteg-alcsoport & 2010 & 2011 & 2012 & 2013 & 2014 & 2015 & Teljes vizsgálati időszak \\
\hline KVA & 108151 & 128748 & 145486 & 153227 & 160816 & 164768 & 263024 \\
\hline NOAC & 46 & 169 & 321 & 1883 & 12494 & 22695 & 25253 \\
\hline Összesen & 108180 & 128874 & 145678 & 154134 & 167978 & 180134 & 271416 & 154 \\
\hline
\end{tabular}

KVA = K-vitamin-antagonista; NOAC = új orális antikoaguláns (új típusú véralvadásgátló)

4. táblázat |A különböző orális antikoagulánsok adherenciájának változásai

\begin{tabular}{|c|c|c|c|c|c|c|c|}
\hline Terápia & & 2010 & 2011 & 2012 & 2013 & 2014 & 2015 \\
\hline \multirow{5}{*}{ KVA } & $<60 \%$ & $19,8 \%$ & $22,9 \%$ & $24,4 \%$ & $23,7 \%$ & $24,1 \%$ & $25,9 \%$ \\
\hline & $60-79 \%$ & $17,2 \%$ & $18,2 \%$ & $18,5 \%$ & $18,1 \%$ & $18,4 \%$ & $18,9 \%$ \\
\hline & $80-89 \%$ & $13,1 \%$ & $13,0 \%$ & $13,4 \%$ & $13,3 \%$ & $13,1 \%$ & $13,6 \%$ \\
\hline & $90 \%+$ & $49,9 \%$ & $46,0 \%$ & $43,7 \%$ & $45,0 \%$ & $44,4 \%$ & $41,6 \%$ \\
\hline & Összesen & $100,0 \%$ & közel 100,0\% & $100,0 \%$ & közel 100,0\% & $100,0 \%$ & $100,0 \%$ \\
\hline \multirow{5}{*}{ NOAC } & $<60 \%$ & $69,6 \%$ & $84,0 \%$ & $55,8 \%$ & $29,2 \%$ & $18,2 \%$ & $19,1 \%$ \\
\hline & $60-79 \%$ & & & $3,7 \%$ & $6,5 \%$ & $9,4 \%$ & $11,2 \%$ \\
\hline & $80-89 \%$ & & & & $6,2 \%$ & $6,1 \%$ & $10,6 \%$ \\
\hline & $90 \%+$ & $26,1 \%$ & $14,2 \%$ & $38,0 \%$ & $58,1 \%$ & $66,3 \%$ & $59,1 \%$ \\
\hline & Összesen & közel 100,0\% & közel 100,0\% & közel 100,0\% & $100,0 \%$ & $100,0 \%$ & $100,0 \%$ \\
\hline
\end{tabular}

KVA = K-vitamin-antagonista; NOAC = új orális antikoaguláns (új típusú véralvadásgátló) 


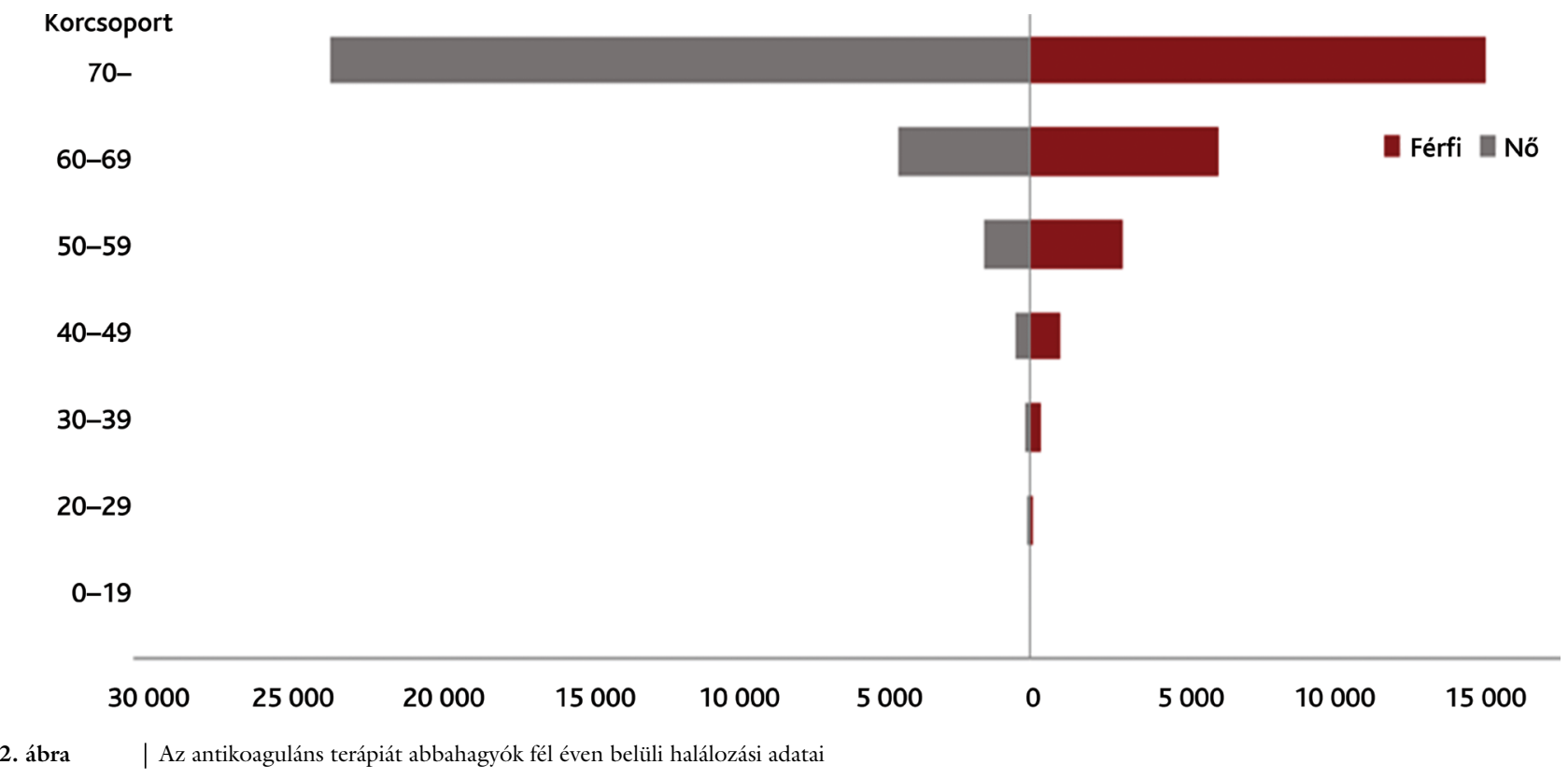

kezelésben, és milyen részben nem kapnak védelmet vagy nem kellően effektív acetilszalicilsav terápiában részesülnek. A K-vitamin-antagonisták közül a hazánkban elterjedt acenocumarolt és warfarint vettük figyelembe, míg a DOAC-ok közül az apixaban-, dabigatran- és rivaroxabanfelhasználást vizsgáltuk. $\mathrm{Az} 1$. táblázat azt mutatja, hogy még mindig a betegek egyharmada nem kap effektív stroke-profilaxis kezelést, és ez az utóbbi években nem is igen változott. A 2. táblázat a nem effektív terápián belül az aszpirint szedők és nem szedők számát mutatja. A 3. táblázat a régi és az új antikoagulánsok megoszlását mutatja, ami csak most kezdődött el és egy növekvő tendenciát mutat. Az új orális antikoagulánsoknál nagyon fontos kérdés/elvárás az adherencia alakulása, amit a 4. táblázat mutat. A releváns antikoaguláns terápiát abbahagyók kor és nem szerinti megoszlását a 2 . ábra illusztrálja. Végezetül a releváns terápiát abbahagyók fél éven belüli halálozásának számadatait nem és kor szerinti megoszlásban az 5. táblázattal demonstráljuk.

\section{Megbeszélés}

A pitvarfibrilláció kezelésének egyik sarokköve a strokeprofilaxist jelentő vérhígító kezelés. Ennek minőségi jellemzői egyben az adott régió egészségügyi ellátásának minőségi indikátorának is tekinthetők. Ugyanakkor az új készítmények megjelenésével lényeges változások kezdődtek meg. Ennek a jellemzőit vizsgáltuk az elmúlt időszakban. Megállapítható, hogy lényeges javulás van a korábbi felmérésünkhöz képest az effektív stroke-profilaxist biztosító kezelés tekintetében. Ugyanakkor a betegek egyharmada nem kap effektív kezelést, illetve a már nem javasolt aszpirinterápiában részesül [2]. Korábbi adataink további megerősítését jelent, hogy prevalenciá- ra az a magasnak számító 3\%-os arány jött ki, ami 300 ezer fős populációt jelent a gyakorlatban. Üdvözlendő, hogy, ahogyan várni is lehetett, az új készítményeknek magasabb az adherenciája, mint a K-vitamin-antagonistákénak, de még mindig van mit javítani. Főleg úgy, hogy ha megnézzük az effektív gyógyszert elhagyók fél éven belül bekövetkező halálozását, akkor ez az adat az összes halálozás egyharmadát teszi ki. Habár egy újabb analízis azt mutatta, hogy pitvarfibrillációban a halálozásért csak kis részben (6\%) tehetők felelőssé az antikoagulációval összefüggő halálozások, és döntő tényező a halálozásban a strukturális szívbetegség (infarktus, szívelégtelenség).

A vizsgálatnak, a fenti megállapítások mellett, vannak hiányosságai, amit itt meg kell említeni:

- Nem vizsgáltuk, nem tudtuk vizsgálni, hogy milyen arányban volt a betegeknek a $\mathrm{CHA}_{2} \mathrm{DS}_{2}$-VASc rizikóbecslése nulla, ami mellett nem indokolt a stroke-profilaxis vagy pedig ellenjavallt az antikoaguláns kezelés.

\begin{tabular}{l|l} 
5. táblázat & $\begin{array}{l}\text { A gyógyszert abbahagyók megoszlása kor és nem szerint azok- } \\
\text { nál, akik a gyógyszer abbahagyása után fél éven belül elhaláloz- } \\
\text { tak }\end{array}$
\end{tabular}

\begin{tabular}{lrrrr}
\hline Korcsoport & Férfi & Nö & Összesen & $\begin{array}{c}\text { Kumulált } \\
\text { arány }\end{array}$ \\
\hline $0-19$ & & & & \\
$20-29$ & & & 10 & $0,1 \%$ \\
$30-39$ & 41 & 115 & 384 & $0,3 \%$ \\
$40-49$ & 269 & 509 & 1055 & $11,9 \%$ \\
$50-59$ & 996 & 6207 & 10650 & $84,6 \%$ \\
$60-69$ & 4443 & 6838 & 12596 & $100,0 \%$ \\
70 felett & 5758 & & & \\
\hline Összesen & & & 44 & \\
\hline
\end{tabular}


- Nem vizsgáltuk, nem tudtuk vizsgálni, hogy mennyire volt a K-vitamin-antagonista kezelés mellett a betegek INR-értéke a terápiás tartományban, ami jelentősen befolyásolja az effektivitást és vérzéses szövődményeket.

- Nem vizsgáltuk, hogy miért volt jobb a DOAC-betegek adherenciája, mint a K-vitamin-antagonista gyógyszert szedő betegeké.

- Végezetül nem vizsgáltuk, hogy a stroke-profilaxist elhagyó betegek mennyiben hagytak el más olyan fontos készítményeket is, amelyek szerepet játszhattak a halálozásukban.

\section{Következtetések}

A pitvarfibrilláció továbbra is egy komoly kihívást jelentő cardiovascularis betegség, ahol az új orális antikoagulánsok bevezetésével javítható volt a betegek adherenciája. Ugyanakkor még mindig csak a betegek kis része részesül ebben a kezelésben, míg a betegek egyharmada nem kap effektív stroke-profilaxist. Az antikoaguláns kezelést elhagyók döntő része 70 év feletti, akiknél magas a fél éven belüli halálozás $[8,9]$.

Feladatunk továbbra is az, hogy a nem stroke-rizikómentes betegeket effektív stroke-profilaxisban részesítsük és a betegek adherenciáját javítsuk.

Anyagi támogatás: A szerzők anyagi támogatásban nem részesültek.

Szerzôi munkamegosztás: T. J.: A cikk megírása. S. B., N. B.: Adatgyứjtés, statisztika. A cikk végleges változatát mindhárom szerző elolvasta és jóváhagyta.

Érdekeltség: A szerzőknek nincsenek érdekeltségeik.

\section{Irodalom}

[1] Tomcsányi J, Bózsik B, Rokszin Gy, et al. The prevalence of atrial fibrillation in Hungary. [A pitvarfibrilláció prevalenciája Magyarországon.] Orv Hetil. 2012; 153: 339-342. [Hungarian]

[2] Heidbuchel H, Verhamme P, Alings M, et al. Updated European Heart Rhythm Association practical guide on the use of non-vitamin $\mathrm{K}$ antagonist anticoagulants in patients with non-valvular atrial fibrillation. Europace 2015; 17: 1467-507.

[3] Connolly SJ, Ezekowitz MD, Yusuf S, et al. Dabigatran versus warfarin in patients with atrial fibrillation. N Engl J Med. 2009; 361: 1139-1151.

[4] Patel MR, Mahaffey KW, Garg J, et al. Rivaroxaban versus warfarin in nonvalvular atrial fibrillation. N Engl J Med. 2011; 365: 883-891.

[5] Granger CB, Alexander JH, McMurray JJ, et al. Apixaban versus warfarin in patients with atrial fibrillation. N Engl J Med. 2011; 365: 981-992.

[6] Giugliano RP, Ruff CT, Braunwald E, et al. Edoxaban versus warfarin in patients with atrial fibrillation. $\mathrm{N}$ Engl J Med. 2013; 369: 2093-2104.

[7] Proietti M, Nobili A, Raparelli V, et al. Adherence to antithrombotic therapy guidelines improves mortality among elderly patients with atrial fibrillation: insights from the REPOSI study. Clin Res Cardiol. 2016; 105: 912-920.

[8] Gómez-Outes A, Lagunar-Ruíz J, Terleira-Fernández AI, et al. Causes of death in anticoagulated patients with atrial fibrillation. J Am Coll Cardiol. 2016; 68: 2508-2521.

[9] Steinberg BA, Shrader A, Thomas L. Off-label dosing of nonvitamin $\mathrm{K}$ antagonist oral anticoagulants and adverse aoutcomes. The Orbit-AF II Registry. J Am Coll Cardiol. 2016; 68: $2597-$ 2604

(Tomcsányi János dr., Budapest, Árpád fejedelem u. 7., 1027 e-mail: tomcsanyij@gmail.com)

\section{„Lumina in tenebris clariora sunt." (Quintilianus) (Sötétben tündöklőbb a fény.)}

